\title{
Persistent severe hypokalemia: Gitelman syndrome and differential diagnosis
}

Hipocalemia grave persistente: Síndrome de Gitelman e diagnósticos diferenciais

\section{Authors}

Christine Zomer Dal Molin ${ }^{1}$

Daisson José Trevisol ${ }^{1,2}$

${ }^{1}$ Universidade do Sul de Santa Catarina.

${ }^{2}$ Hospital Nossa Senhora da Conceição.
Submitted on: 12/6/2016. Approved on: 2/13/2017.

\footnotetext{
Correspondence to:

Christine Zomer Dal Molin. Universidade do Sul de Santa Catarina.

Av. José Acácio Moreira, 787, Bairro Dehon, Tubarão, SC, Brazil.

CEP: 88704-900

E-mail: christinezdm@hotmail. com
}

DOI: $10.5935 / 0101-2800.20170058$

\section{Abstract}

The main causes of hypokalemia are usually evident in the clinical history of patients, with previous episodes of vomiting, diarrhea or diuretic use. However, in some patients the cause of hypokalemia can become a challenge. In such cases, two major components of the investigation must be performed: assessment of urinary excretion potassium and the acid-base status. This article presents a case report of a patient with severe persistent hypokalemia, complementary laboratory tests indicated that's it was hypomagnesaemia and hypocalciuria associated with metabolic alkalosis, and increase of thyroid hormones. Thyrotoxic periodic paralysis was included in the differential diagnosis, but evolved into euthyroid state, persisting with severe hypokalemia, which led to be diagnosed as Gitelman syndrome.

Keywords: hypokalemia; Gitelman syndrome; hyperthyroidism; hypokalemic periodic paralysis.

\section{INTRODUCTION}

Hypokalemia is a common clinical problem. Situations that decrease intake, increase translocation into the cells or increase losses in the urine, gastrointestinal tract, or sweat lead to a reduction in the serum potassium concentration, resulting in hypokalemia and its clinical manifestations. ${ }^{1}$

After hypokalemia is documented, attempts should be made based on the history and laboratory findings to identify the cause, which is often secondary to vomiting, diarrhea or diuretic therapy. Assessment of a hypokalemic patient begins with the evaluation of muscle strength

\section{Resumo}

As principais causas de hipocalemia normalmente são evidentes na história clínica dos pacientes em investigação etiológica, com episódios prévios de vômitos, diarréia ou uso de diuréticos. Entretanto, em alguns pacientes, a causa da hipocalemia pode se tornar um desafio. Em tais casos, dois principais componentes da investigação devem ser realizados: avaliação da excreção do potássio urinário e do "status" ácido-básico. Este artigo traz um relato de caso de uma paciente portadora de hipocalemia grave persistente, com investigação laboratorial complementar caracterizada por hipomagnesemia e hipocalciúria, associada à alcalose metabólica $\mathrm{e}$ elevação dos hormômios tireoideanos. A apresentação inicial do quadro incluiu paralisia periódica tireotóxica como um dos principais diagnósticos diferenciais, porém, a paciente evoluiu para um estado eutireoideo e persistiu com grave hipocalemia, sendo, por fim, realizado diagnóstico clínico de Síndrome de Gitelman.

Palavras-chave: hipopotassemia, síndrome de Gitelman, hipertireoidismo, paralisia periódica hipopotassêmica.

and obtaining an electrocardiogram (EKG) test to assess the cardiac consequences. ${ }^{2-5}$

This article presents a case report of a patient with severe persistent hypokalemia, with complementary laboratory findings characterized by hypomagnesaemia and hypocalciuria associated with metabolic alkalosis, and increase of thyroid hormones.

\section{Case report}

A 41-year-old Brazilian woman was referred to Nephrologist with complaints of weakness, fatigue and muscle crumps. She was first admitted to a Intensive Care Unit of a tertiary hospital eight months before the first visit to our clinic with 
the symptoms previously mentioned. The symptoms were exacerbated by vomiting, nausea and diarrhea, and associated with EKG abnormalities and severe hypokalemia.

Then, she was admitted to a hospital two times more, due to the same symptoms and laboratory findings, but this time without vomiting and diarrhea, and also no EKG repercussion. Blood biochemical analysis showed hypokalaemic $(1.8-2.2 \mathrm{mEq} / \mathrm{L})$ metabolic alkalosis (pH 7.5 / bicarbonate $32.1 \mathrm{mEq} / \mathrm{L}$ ) with hypocalciuria $(2.26 \mathrm{mg} / 24 \mathrm{~h})$, hypomagnesaemia $(1.6 \mathrm{mg} /$ $\mathrm{dL})$ and normal serum calcium $(1.17 \mathrm{mmol} / \mathrm{L})$. Her thyroid-stimulating hormone (TSH) level was lower than $0.01 \mu \mathrm{UI} / \mathrm{mL}$, thyroxine (fT4) level was higher than $3.23 \mathrm{ng} / \mathrm{dl}$, demonstrating overt hyperthyroidism. Renal function was normal, as well as parathormone $(50 \mathrm{pg} / \mathrm{mL})$ and albumin $(4.3 \mathrm{~g} / \mathrm{dL})$ levels.

Past history of weight loss, not quantified, associated with amenorrhea and low blood pressure. She had thyroid cancer 20 years ago, when she was submitted to thyroidectomy. She had a cancer relapse, five years ago, treated with radioactive iodine therapy. She was taking regularly oral levothyroxine 100 mcg daily.

Family history of cancer in two family members, not related to thyroid cancer, and her father suffered an acute myocardial infarction. She had no history of abuse of laxatives or diuretics.

Renal ultrasound was normal. The clinical examination results showed that her height was $1.57 \mathrm{~m}$ and her weight was $38 \mathrm{~kg}$ (Body Mass Index $=15.4 \mathrm{~kg} /$ $\mathrm{m}^{2}$ ). There was no prominent bulging of the eyes, her pulse rate was 84 beats per minute without arrhythmia, and the cardiac auscultation area had no pathological murmurs.

Upon admission to our clinic, the patient was taking an overdose of levothyroxine; therefore, thyrotoxic hypokalemic periodic paralysis (THPP) was considered the cause of the hypokalemic paralysis. The levothyroxine dose was diminished up to 75 mcg daily.

However, despite euthyroid status and potassium and magnesium replacement, the severe hypokalemic condition persisted. Then, further investigations were made to reveal the etiology, and Gitelman Syndrome (GS) was considered. New laboratory tests revealed: creatinine $1.26 \mathrm{mg} / \mathrm{dl}$; magnesium $2.8 \mathrm{meq} / \mathrm{L}$; sodium $130 \mathrm{meq} / \mathrm{L}$; potassium $1.8 \mathrm{meq} / \mathrm{L}$; chloride ur $80 \mathrm{mEq} / \mathrm{L}$; calcium ur $29.2 \mathrm{mg} / 24 \mathrm{~h}$; magnesium ur $32.6 \mathrm{mg} / 24 \mathrm{~h}$; sodium ur $74 \mathrm{mmol} / 24 \mathrm{~h}$; potassium ur
$32 \mathrm{mEq} / 24 \mathrm{~h}$; chloride $73 \mathrm{mmol} / \mathrm{L}$; TSH $4.03 \mu \mathrm{UI} / \mathrm{mL}$; T4 livre $1.3 \mathrm{ng} / \mathrm{dl}$; blood gases $\mathrm{pH} 7.46$ / bicarbonate $40 \mathrm{mEq} / \mathrm{L}$. She had elevated levels of aldosterone and renin activity, $212 \mathrm{ng} / \mathrm{dL}$ and $215 \mathrm{ng} / \mathrm{mL}$, respectively.

Because of a high risk of volume depletion in our patient, who was already presenting low blood pressure (systolic blood pressure around $80-90 \mathrm{mmHg}$ ), diuretic tests were not performed. Literature recommends performing the test in normotensive patients with hypokalemic alkalosis phenotype, in which an abnormal test allows to predict with a very high sensitivity and specificity the GS genotype and thus avoid the need for genotyping. ${ }^{6}$ Genetic studies were not performed, so far, because of its high cost.

\section{Discussion}

THPP is a rare metabolic myopathy that consists of acute systemic muscle weakness associated with hypokalemia, with potentially fatal episodes of muscle weakness or paralysis that can affect the respiratory muscles. The most common cause of hypokalemic paralysis is primary or may be familial hypokalemic periodic paralysis.

The familial forms have a genetic substrate, autosomal dominant penetrance, and the symptoms occur due to hereditary defects in the ion channels, in younger individuals. Sporadic paralysis are related to the dysfunction of ion channels caused by electrolytic disturbances, as the patient in this case report. The causes of sporadic forms could include secondary to thyrotoxicosis, renal tubular acidosis, primary hyperaldosteronism, Gitelman syndrome (GS), diarrhea or barium intoxication. ${ }^{7}$

THPP occurs predominantly in Asian male descendants. The thyrotoxic condition causes an ion channel defect leading to a rapid shift of potassium into the intracellular space. ${ }^{7}$

Serum potassium levels may decline to as low as 1.5 to $2.5 \mathrm{mEq} / \mathrm{L}$ in acute attacks, which are precipitated by rest after exercise, carbohydrate meal or stress. Serum potassium is normal during periods between the attacks of paralysis. This is a characteristic that can help distinguish periodic paralysis from other forms of hypokalemic paralysis.

Patients with THPP will also have a low urinary potassium excretion; wich, can also help distinguish patients from those who have hypokalemic paralysis due to renal loss of potassium. ${ }^{8}$ Our patient evolved into euthyroid state, persisting with severe 
hypokalemia, then clinical diagnosis of Gitelman syndrome (GS) was made.

GS is an autosomal recessive renal tubular disease with clinical manifestations similar to those of Bartter syndrome (BS). Its main clinical features of this disease are hypokalemia, hypomagnesemia, low urinary calcium, and high aldosterone and renin levels with normal blood pressure. ${ }^{6,9-11}$

GS is a rare inherited autosomal recessive tubulopathy that causes loss of salt, characterized by hypokalemic metabolic alkalosis, hypomagnesemia, hypocalciuria, and secondary hyperaldosteronism. ${ }^{11,12} \mathrm{It}$ is mainly related to mutations in the SLC12A3 gene encoding for the thiazide-sensitive $\mathrm{NaCl}$ cotransporter of the distal convoluted tubule. ${ }^{6,711-14}$

In contrast to BS, GS is known to be characterized by more frequent hypomagnesemia and low urinary calcium excretion. ${ }^{10}$

GS is very often asymptomatic. ${ }^{6}$ The natural history of GS is variable in terms of age at clinical diagnosis, biologic phenotype, and clinical manifestations. ${ }^{12}$ Most of the patients with GS are asymptomatic or complain of mild intermittent cramps, fatigue, muscle weakness, or irritability. Thirst, polyuria, carpopedal spasm, paraesthesiae, palpitations and joint pain are related to the disorder as well. 5,8,12,15

The phenotypic variations and the absence of a standard diagnostic method make a definite diagnosis of GS more difficult. ${ }^{9}{ }^{16}$ Nevertheless, even without a genetic report, clinicians should be able to make correct clinical diagnosis, predict prognosis, and manage the condition correctly. ${ }^{10}$

The aims of treatment are to improve patient symptoms, quality of life and serum electrolyte levels, and to ensure cardiac rhythm stability. Standard treatment includes a diet with high levels of salt, potassium and magnesium, as well as oral magnesium and potassium supplements, sometimes together with K-sparing diuretics (if hypotension permits). ${ }^{6,9}$

In summary, in our case report, the patient had concurrent THPP and GS, two simultaneous pathological mechanisms triggered by hypokalemia. ${ }^{15}$ Clinical findings did not provide clues for a pathological condition other than thyrotoxicosis. ${ }^{17}$ Hypokalemia is recognized as the first possible symptom for patients with GS and THPP. The difference between them is that patients with THPP often have transient hypokalaemia. ${ }^{18}$
In the medical literature, there are only two case reports describing hypokalemic paralysis due to thyrotoxicosis accompanied by GS. One report in a 16-year-old Japanese male patient ${ }^{13}$ and another, of a 35 -year-old Indian male. ${ }^{7}$ We have also found, two letters to the editor, describing four cases of Asian females with concurrent diagnosis of Grave's disease and GS. ${ }^{18,19}$ So far, our case is the first case report of a Brazilian female with concurrent symptoms of hyperthyroidism and Gitelman Syndrome. The authors also did not find any other cases reporting periodic paralysis to hiperthyroidism due to drugs.

\section{Acknowledgements}

Informed consent was obtained from the patient and the article was submitted to the Ethical Committee of the Institution. The authors would like to express their deepest gratitude to the patient for sharing her clinical data. The authors declare that there is no conflict of interest regarding the publication of this article.

\section{References}

1. Squires RD, Huth EJ. Experimental potassium depletion in normal human subjects. I. Relation of ionic intakes to the renal conservation of potassium. J Clin Invest 1959;38:1134-48. PMID: 13664789 DOI: http://dx.doi.org/10.1172/JCI103890

2. Adrogué HJ, Madias NE. Changes in plasma potassium concentration during acute acid-base disturbances. Am J Med 1981;71:456-67. PMID: 7025622 DOI: http://dx.doi. org/10.1016/0002-9343(81)90182-0

3. Chen EH, Hollander JE. When do patients need admission to a telemetry bed? J Emerg Med 2007;33:53-60.

4. Drew BJ, Califf RM, Funk M, Kaufman ES, Krucoff MW, Laks MM, et al.; American Heart Association; Councils on Cardiovascular Nursing, Clinical Cardiology, and Cardiovascular Disease in the Young. Practice standards for electrocardiographic monitoring in hospital settings: an American Heart Association scientific statement from the Councils on Cardiovascular Nursing, Clinical Cardiology, and Cardiovascular Disease in the Young: endorsed by the International Society of Computerized Electrocardiology and the American Association of Critical-Care Nurses. Circulation 2004;110:2721-46. DOI: http:// dx.doi.org/10.1161/01.CIR.0000145144.56673.59

5. Gjata M, Tase M, Gjata A, Gjergji Z. Gitelman's syndrome (familial hypokalemia-hypomagnesemia). Hippokratia 2007;11:150-3.

6. Al Shibli A, Narchi H. Bartter and Gitelman syndromes: Spectrum of clinical manifestations caused by different mutations. World J Methodol 2015;5:55-61.

7. Baldane S, Ipekci SH, Celik S, Gundogdu A, Kebapcilar L. Hypokalemic paralysis due to thyrotoxicosis accompanied by Gitelman's syndrome. Indian J Nephrol 2015;25:103-5. DOI: http://dx.doi.org/10.4103/0971-4065.140719

8. Lin SH, Lin YF, Chen DT, Chu P, Hsu CW, Halperin ML. Laboratory tests to determine the cause of hypokalemia and paralysis. Arch Intern Med 2004;164:1561-6. PMID: 15277290 DOI: http://dx.doi.org/10.1001/archinte.164.14.1561

9. Robinson CM, Karet Frankl FE. Magnesium lactate in the treatment of Gitelman syndrome: patient-reported outcomes. Nephrol Dial Transplant 2017;32:508-12. 
10. Lee JW, Lee J, Heo NJ, Cheong HI, Han JS. Mutations in SLC12A3 and CLCNKB and Their Correlation with Clinical Phenotype in Patients with Gitelman and Gitelman-like Syndrome. J Korean Med Sci 2016;31:47-54. DOI: http://dx.doi. org/10.3346/jkms.2016.31.1.47

11. Miao M, Zhao CQ, Wang XL, Shan ZY. Clinical and genetic analyses of Chinese patients with Gitelman syndrome. Genet Mol Res 2016;15. DOI: http://dx.doi.org/10.4238/ gmr.15027859

12. Blanchard A, Vargas-Poussou R, Vallet M, Caumont-Prim, A, Allard J, Desport E, et al. Indomethacin, amiloride, or eplerenone for treating hypokalemia in Gitelman syndrome. J Am Soc Nephrol 2015;26:468-75. PMID: 25012174 DOI: http:// dx.doi.org/10.1681/ASN.2014030293

13. Eren MA, Tabur S, Sezgin B, Sabuncu T. A rare cause of hypokalemia: Gitelman syndrome. Eur J Gen Med 2011;8:154-6.

14. Mazzeo T, Boselli Junior JR, Barnett JR, Vianna ACA, Matni AM, Delfino VDA, et al. Relato de caso: Aspectos clínicos e fisiopatológicos da syndrome de Gitelman - três casos. J Bras Nefrol 2001;23:40-4.
15. Kulkarni M, Kadri P, Pinto R. A case of acquired Gitelman syndrome presenting as hypokalemic paralysis. Indian J Nephrol 2015;25:246-7. DOI: http://dx.doi.org/10.4103/09714065.146031

16. Mukhopadhyay S, Jana S, Chatterjee A, Roy M, Sarkar A, Mukhopadhyay J. Quadriparesis due to Gitelman's syndrome diagnosed with thiazide diuretic test response. Saudi J Kidney Dis Transpl 2016;27:407-10. DOI: http://dx.doi. org/10.4103/1319-2442.178584

17. Imashuku S, Teramura-Ikeda T, Kudo N, Kaneda S, Tajima T. Concurrence of thyrotoxicosis and Gitelman's syndrome-associated hypokalemia-induced periodic paralysis. Pediatr Rep 2012;4:e18. DOI: http://dx.doi.org/10.4081/pr.2012.e18

18. Mizokami T, Hishinuma A, Kogai T, Hamada K, Maruta T, Higashi $\mathrm{K}$, et al. Graves' Disease and Gitelman syndrome. Clin Endocrinol (Oxf) 2016;84:149-50. DOI: http://dx.doi. org $/ 10.1111 /$ cen.12829

19. Zha B, Zheng P, Liu J, Huang X. Coexistence of Graves' Disease in a 14-year-old young girl with Gitelman Syndrome. Clin Endocrinol (Oxf) 2015;83:995-7. DOI: http://dx.doi. org/10.1111/cen.12800 